\title{
Tumor Necrosis Factor- $\alpha$ Inhibits Stem Cell Factor-induced Proliferation of Human Bone Marrow Progenitor Cells In Vitro

\author{
Role of p55 and p75 Tumor Necrosis Factor Receptors
}

\author{
Leiv S. Rusten, Erlend B. Smeland, Frede W. Jacobsen, Eli Lien, Wemer Lesslauer, * Hansruedi Loetscher, * \\ Claire M. Dubois, ${ }^{\star}$ and Sten Eirik W. Jacobsen \\ Department of Immunology, Institute for Cancer Research, The Norwegian Radium Hospital, N-0310 Oslo, Norway; *Department of \\ Biology Pharmaceutical Research New Technologies, F. Hoffmann-LaRoche, CH-4002 Basel, Switzerland; and ${ }^{\ddagger}$ Immunology Division, \\ Faculty of Medicine Department of Pediatrics, University of Sherbrooke, Sherbrooke, Quebec, Canada J1H 5N4
}

\begin{abstract}
Stem cell factor (SCF), a key regulator of hematopoiesis, potently synergizes with a number of hematopoietic growth factors. However, little is known about growth factors capable of inhibiting the actions of SCF. TNF- $\alpha$ has been shown to act as a bidirectional regulator of myeloid cell proliferation and differentiation. This study was designed to examine interactions between TNF- $\alpha$ and SCF. Here, we demonstrate that TNF- $\alpha$ potently and directly inhibits SCF-stimulated proliferation of $\mathrm{CD34}^{+}$hematopoietic progenitor cells. Furthermore, TNF- $\alpha$ blocked all colony formation stimulated by SCF in combination with granulocyte colony-stimulating factor (CSF) or CSF-1. The synergistic effect of SCF observed in combination with GM-CSF or $\mathbf{L - 3}$ was also inhibited by TNF- $\alpha$, resulting in colony numbers similar to those obtained in the absence of SCF. These effects of TNF$\alpha$ were mediated through the p55 TNF receptor, whereas little or no inhibition was signaled through the p75 TNF receptor. Finally, TNF- $\alpha$ downregulated c-kit cell-surface expression on $\mathrm{CD}^{+} 4^{+}$bone marrow cells, and this was predominantly a p55 TNF receptor-mediated event as well. $(J$. Clin. Invest. 1994. 94:165-172.) Key words: tumor necrosis factor • kit ligand - hematopoietic cell growth factors $\bullet$ receptors, hematopoietic growth factors $\bullet$ hematopoietic stem cells
\end{abstract}

\section{Introduction}

TNF- $\alpha$ is a pleiotropic cytokine shown to act as both a positive and a negative regulator of myeloid cell proliferation and differentiation (1-9). The effects of TNF- $\alpha$ can be either directly mediated $(7,10)$ or indirectly mediated by inducing other cells to produce hematopoietic growth factors (HGFs) ${ }^{1}$ (11-13).

Address correspondence to Leiv S. Rusten, M.D., Department of Immunology, Institute for Cancer Research, The Norwegian Radium Hospital, N-0310 Oslo, Norway.

Received for publication 15 November 1993 and in revised form 4 April 1994.

1. Abbreviations used in this paper: CSF, colony-stimulating factor; GCSF, granulocyte CSF; HGF, hematopoietic growth factor; HPP-CFC, high proliferative potential colony-forming cell; IMDM, Iscove's modified Dulbecco's medium; pa, polyclonal antibody; rHu, recombinant human; SCF, stem cell factor; TNFR-p55 and TNFR-p75, 55- and 75kD TNF receptors.

J. Clin. Invest.

(c) The American Society for Clinical Investigation, Inc.

0021-9738/94/07/0165/08 \$2.00

Volume 94, July 1994, 165-172
Recently, two TNF receptors (TNFR), with molecular masses of 55 (TNFR-p55) and $75 \mathrm{kD}$ (TNFR-p75), have been identified and cloned (14-18). TNF- $\alpha$ was originally thought of as a potential cancer therapeutic agent because of its cytotoxic activity in neoplastic cell lines and antitumor activity in certain transplanted mouse tumors (19). However, treatment of cancer patients with TNF- $\alpha$ has been hampered by severe toxic side effects, although TNF- $\alpha$ still may have therapeutic potential (20-27).

We have demonstrated recently that TNFR-p55 exclusively mediates the stimulatory effects of TNF- $\alpha$ on GM-CSF and IL3-induced colony formation, as well as inhibition of granulocyte colony-stimulating factor (G-CSF)-induced colony growth (28). In contrast, both TNFR-p55 and TNFR-p75 can reversibly signal inhibition of more primitive progenitor cells such as high proliferative potential colony-forming cells (HPP-CFC) $(28,28 \mathrm{a})$.

Stem cell factor (SCF), a newly defined hematopoietic growth factor encoded at the Steel locus of the mouse, is the ligand for the c-kit tyrosine kinase receptor which is encoded at the dominant-white spotting locus of the mouse (29-33). SCF has emerged as a key regulator of hematopoietic progenitor cell growth. As a single factor, SCF is a weak stimulus for hematopoietic progenitor cell growth. However, it synergizes potently with the colony-stimulating factors (CSFs), IL-1, IL6 , IL-11, IL-12, and erythropoietin to stimulate progenitor cells of the myelomonocytic, erythroid, and megakaryocytic lineages (34-43). In humans, SCF has been demonstrated to preferentially promote the survival and proliferation of primitive progenitor cells, whereas more committed progenitors are stimulated to a lesser extent $(34,36)$.

The present studies were designed to investigate the effects of TNF- $\alpha$ on $\mathrm{CD}_{3} 4^{+}$progenitor cell proliferation induced by SCF alone or in combination with CSFs. Here, we demonstrate for the first time that TNF- $\alpha$ directly and mainly through the p55 TNF receptor can inhibit SCF-stimulated proliferation of human hematopoietic progenitor cells.

\section{Methods}

HGFs. Purified recombinant human ( $\mathrm{rHu}$ ) G-CSF and rHuSCF were generously supplied by Dr. Ian K. McNiece (Amgen Inc., Thousand Oaks, CA). rHuGM-CSF and rHuIL-3 were generously provided by Dr. Steven Gillis (Immunex Corp., Seattle, WA). rHuTGF- $\beta_{1}$ was a kind gift from Dr. Tony Purchio (Oncogene Corp., Seattle, WA). rHuCSF-1 was kindly supplied by Dr. Michael Geier (Cetus Corp., Emeryville, CA). HuTNF- $\alpha$ mutants specific for TNFR-p55 and TNFRp75 were prepared by site-directed mutagenesis (44). Solid phase binding studies have shown that the $\operatorname{Trp}^{32} \mathrm{Thr}^{86} \mathrm{TNF}-\alpha$ mutant protein binds with wild-type affinity to TNFR-p55 and does not bind at all to TNFRp75, whereas the Asn ${ }^{143} \operatorname{Arg}^{145}$ TNF- $\alpha$ mutant protein exclusively binds 
to TNFR-p75, although with a 5-10-fold lower affinity than wild-type TNF- $\alpha$ (44). Both mutant proteins were titrated and used at optimal concentrations.

Unless otherwise indicated, all growth factors were used at predetermined optimal concentrations: $\mathrm{rHuG}-\mathrm{CSF}(20 \mathrm{ng} / \mathrm{ml})$, rHuGM-CSF ( 50 $\mathrm{ng} / \mathrm{ml})$, rHuIL-3 (20 ng/ml), rHuSCF ( $50 \mathrm{ng} / \mathrm{ml})$, rHuCSF-1 (50 ng/ $\mathrm{ml})$, and rHuTGF- $\beta_{1}(20 \mathrm{ng} / \mathrm{ml})$.

Antibodies against human TNF receptors. Rabbit anti-human TNFR-p75 (also named TNFR $\alpha$ or TNF-R2) polyclonal antibodies with TNF- $\alpha$ agonistic activity (paTNFR-p75) were raised by immunization of rabbits with soluble TNFR-p75 and prepared as described previously (45). An mAb against TNFR-p55 (also named TNFR $\beta$ or TNF-R1) with TNF- $\alpha$ agonistic activity (htr-9) was obtained after immunization of mice with a TNF-binding protein purified from HL-60 cells (46). htr-9 and paTNFR-p75 were titrated and used at optimal concentrations ( 10 and $2 \mu \mathrm{g} / \mathrm{ml}$, respectively).

Cell separation. Human bone marrow cells were obtained by iliac crest aspiration from normal adult volunteers with informed consent and the approval of the Ethics Committee of The Norwegian Radium Hospital. Mononuclear cells were isolated by Ficoll-Hypaque gradient centrifugation (Lymphoprep; Nycomed Pharma, Oslo, Norway). Positive selection of $\mathrm{CD} 34^{+}$cells was performed according to a previously described method (47). Briefly, bone marrow mononuclear cells were rosetted with Dynabeads M-450 (product 111.10; Dynal, Oslo, Norway) directly coated with the CD34 mAb BI-3C5 for $45 \mathrm{~min}$ at $4^{\circ} \mathrm{C}$ on an apparatus that provided tilting and gentle rotation. The bead to total cell ratio was 1:1. Rosetted cells were attracted to a samarium cobalt magnet, and nonrosetting cells were removed by pipetting and washed $(\times 7)$. Detachment of beads from positively selected cells was performed by incubation with anti-Fab antiserum (DETACHaBEAD; Dynal) at a concentration of $35 \mathrm{mg} / \mathrm{ml}$ for $1 \mathrm{~h}$ at room temperature. Isolated cells, free of beads, were washed and counted. The purity of CD34 ${ }^{+}$cells isolated by this method was reproducibly $>90 \%$ as determined by flow cytometric analysis.

Colony assay. A modification of a previously described method (48) was used to assay bone marrow progenitor cells in semisolid medium. $\mathrm{CD} 34^{+}$cells were plated in tissue-culture grade $35-\mathrm{mm}$ Petri dishes in a volume of $1 \mathrm{ml}$ Iscove's modified Dulbecco's medium (IMDM) (Gibco, Paisley, UK) containing 20\% FCS (Sera-lab, Sussex, UK), 5 $\times 10^{-5} \mathrm{M}$ 2-mercaptoethanol, $300 \mathrm{mg} /$ liter glutamine, $66 \mathrm{mg} /$ liter penicillin and $100 \mathrm{mg} /$ liter streptomycin (complete IMDM), and $0.3 \%$ Seaplaque agarose (FMC Corp. BioProducts, Rockville, ME). After 2 wk of incubation at $37^{\circ} \mathrm{C}$ and $5 \% \mathrm{CO}_{2}$ in air, colonies ( $>40$ cells) or clusters ( $4-40$ cells) were counted using an inverted microscope.

Single-cell proliferation assay. CD34 ${ }^{+}$cells were seeded in Terasaki plates (Greiner, Frickenhausen, Germany) at a concentration of one cell per well (300 wells per group) in $20 \mu \mathrm{l}$ complete IMDM. In some experiments, a cell sorter (Epics Elite; Coulter Corp., Hialeah, FL) equipped with a single-cell depositor was used to plate one CD $34^{+}$cell per well. Wells were scored for proliferation after $2 \mathrm{wk}$ of incubation at $37^{\circ} \mathrm{C}$ and $5 \% \mathrm{CO}_{2}$ in air.

Receptor studies. Freshly isolated CD34 ${ }^{+}$cells were incubated in complete IMDM at $37^{\circ} \mathrm{C}$ and $5 \% \mathrm{CO}_{2}$ in air, at a concentration of 1.0 $\times 10^{6}$ cells $/ \mathrm{ml}$. TNF- $\alpha(20 \mathrm{ng} / \mathrm{ml})$ and $/$ or TGF- $\beta_{1}(20 \mathrm{ng} / \mathrm{ml})$ was added 1,6 , or $24 \mathrm{~h}$ before harvest, while htr-9 $(10 \mu \mathrm{g} / \mathrm{ml})$ or paTNFRp75 $(2 \mu \mathrm{g} / \mathrm{ml})$ was added $24 \mathrm{~h}$ before harvest only. Then, the cells were washed, and indirect immunofluorescence staining was performed according to standard techniques with a mouse $\mathrm{mAb}\left(\mathrm{IgG}_{2 \mathrm{a}}\right)$ against human c-kit (SR-1; a gift from Dr. Virginia C. Broudy, University of Washington, Seattle, WA) (49) and with fluorochrome-conjugated goat anti-mouse Ig (Southern Biotechnology Associates, Birmingham, AL) as second layer. An isotype-matched irrelevant mAb served as negative control. To block unspecific binding via $\mathrm{Fc}$ receptors, aggregated human immunoglobulin G (DAKOPATTS, Copenhagen, Denmark) was included at a concentration of $100 \mu \mathrm{g} / \mathrm{ml}$. Flow cytometric analyses were performed on a FACScan ${ }^{\oplus}$ flow cytometer (Becton, Dickinson \& Co., Mountain View, CA) equipped with an argon-ion laser tuned at $488 \mathrm{~nm}$.
Data acquisition and analysis were performed using LYSIS II software (Becton Dickinson Immunocytometry Systems, San Jose, CA).

Cell morphology. CD34 ${ }^{+}$cells were plated in complete IMDM and incubated for $2 \mathrm{wk}$ at $37^{\circ} \mathrm{C}$ and $5 \% \mathrm{CO}_{2}$ in air in the presence or absence of TNF- $\alpha$, or TNF- $\alpha$ mutant proteins specific for either of the two receptor types, and with growth factors as indicated. Cell morphology was determined following May-Gruinwald Giemsa staining of cytospin preparations.

Statistical analysis. All results were expressed as the mean \pm SEM of data obtained from three or more separate experiments. The statistical significance of differences between group means was determined using the Student's $t$ test.

\section{Results}

Effects of TNF- $\alpha$ on colony formation of $\mathrm{CD} 34^{+}$progenitor cells in response to SCF in combination with CSFs. We and others have shown previously that TNF- $\alpha$ is a potent and reversible inhibitor of colony formation of human $\mathrm{CD} 34^{+}$bone marrow cells stimulated by G-CSF or CSF-1, while it stimulates GM-CSF and IL-3-induced colony formation $(6-9,28)$. In the present study, we focused on the ability of TNF- $\alpha$ to affect proliferation of $\mathrm{CD} 34^{+}$bone marrow progenitors stimulated by $\mathrm{SCF}$, alone or in combination with CSFs. As reported previously $(34,35)$, SCF was a weak stimulator of colony formation $(>40$ cells) as a single growth factor. However, an average of 32 clusters ( $4-40$ cells) per $2,000 \mathrm{CD} 34^{+}$cells plated was obtained in response to SCF (50 ng/ml; Fig. $1 A)$, and TNF- $\alpha(20 \mathrm{ng} /$ $\mathrm{ml})$ inhibited SCF-induced cluster formation by $75 \%(P$ $<0.05$ ). Thus, TNF- $\alpha$ potently inhibits SCF-induced proliferation of $\mathrm{CD}^{+} 4^{+}$progenitor cells. Next, the effects of TNF- $\alpha$ were investigated on colony formation of $\mathrm{CD}_{34}{ }^{+}$bone marrow progenitors in response to SCF in combination with the four CSFs. TNF- $\alpha(20 \mathrm{ng} / \mathrm{ml})$ completely inhibited colony formation stimulated by G-CSF plus SCF as well as with G-CSF alone (Fig. $1 B$ ). Similarly, TNF- $\alpha$ also blocked all colony formation stimulated by CSF-1 in combination with SCF (Fig. $1 B$ ). In contrast, and as reported previously $(7,8)$, TNF- $\alpha$ stimulated or had no effect on colony formation induced by GM-CSF or IL-3 (Fig. $1 C$ ). However, the potent synergistic effect observed when SCF was combined with GM-CSF or IL3 was inhibited by TNF- $\alpha$, resulting in colony numbers similar to those obtained in the absence of SCF (Fig. $1 C$ ).

Since it has been shown that the effects of TNF- $\alpha$ (stimulatory or inhibitory) depend on the concentration of TNF- $\alpha$ in culture $(6,7,19)$, we examined the concentration response of TNF- $\alpha$ on G-CSF plus SCF and GM-CSF plus SCF-induced colony formation. 50\% inhibition of G-CSF plus SCF-induced colony formation occurred at a TNF- $\alpha$ concentration of $0.2 \mathrm{ng} /$ $\mathrm{ml}$, while complete inhibition was observed at $20 \mathrm{ng} / \mathrm{ml}$ (Fig. $2 A$ ). Similarly, the dominant effect of TNF- $\alpha$ on GM-CSF plus SCF-induced colony formation was inhibitory, with maximum inhibition (70\%) occurring at a TNF- $\alpha$ concentration of 200 $\mathrm{ng} / \mathrm{ml}$ (Fig. $2 B$ ). Although not statistically significant $(P$ $=0.27$ ), a weak stimulation of $21 \%$ was observed at a TNF$\alpha$ concentration of $0.2 \mathrm{ng} / \mathrm{ml}$.

The TNF- $\alpha$-induced inhibition of SCF-stimulated proliferation is directly mediated. Although $\mathrm{CD}_{3}{ }^{+}$bone marrow cells represent a highly enriched population of progenitor cells, there is still considerable heterogeneity within the $\mathrm{CD} 34^{+}$cell compartment. Indirect effects through cytokine production from accessory cells can therefore not be excluded when effects of TNF- $\alpha$ are studied using CD34 ${ }^{+}$cells at high density. There- 


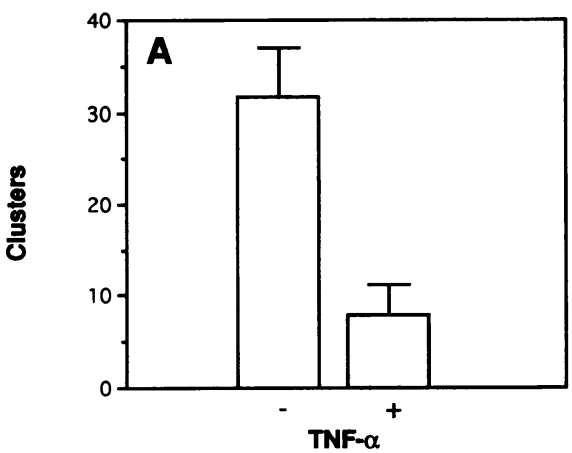

SCF

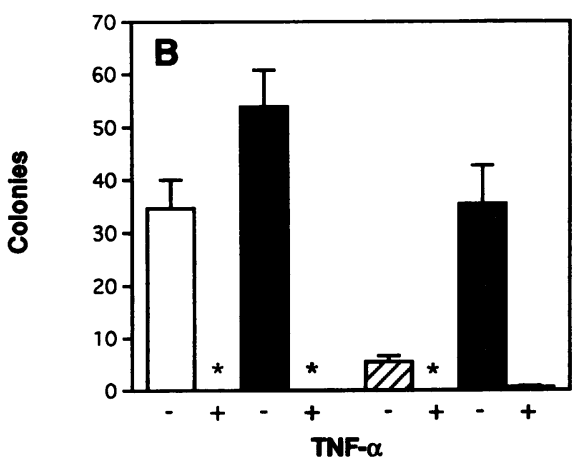

G-CSF

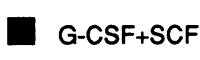

$\square$ CSF-1

CSF-1+SCF

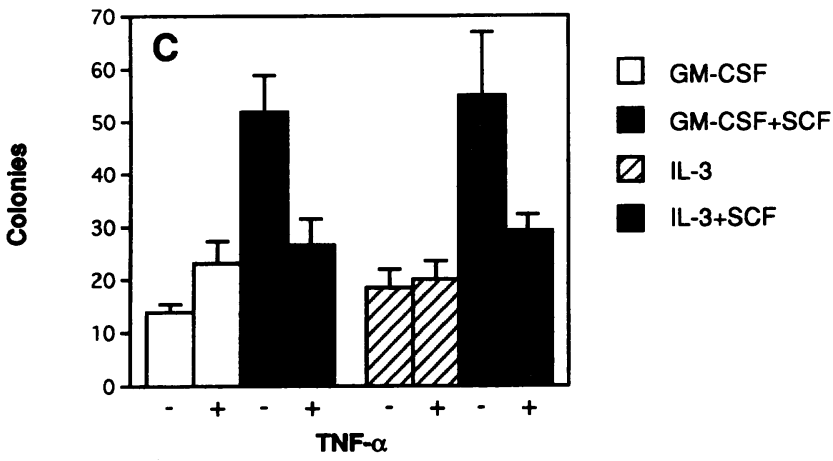

Figure 1. Effects of TNF- $\alpha$ on SCF-induced proliferation of CD $34^{+}$ human bone marrow cells. CD34 ${ }^{+}$cells were isolated and plated in agarose (see Methods) in the presence or absence of TNF- $\alpha$ ( $20 \mathrm{ng}$ / $\mathrm{ml}$ ) and predetermined optimal concentrations of G-CSF $(20 \mathrm{ng} / \mathrm{ml})$, GM-CSF $(50 \mathrm{ng} / \mathrm{ml}), \mathrm{IL}-3(20 \mathrm{ng} / \mathrm{ml})$, or CSF-1 $(50 \mathrm{ng} / \mathrm{ml})$. Cultures were scored for cluster growth ( $4-40$ cells; $A$ ) or colony growth ( $>40$ cells; $B$ and $C$ ) after $14 \mathrm{~d}$ of incubation at $37^{\circ} \mathrm{C}$ and $5 \% \mathrm{CO}_{2}$ in air. Results are presented as the mean number of colonies per $2 \times 10^{3}$ cells $(A)$ or $1 \times 10^{3}$ cells $\left(B\right.$ and $C$; except $4 \times 10^{3}$ cells with CSF-1) from at least four independent experiments with duplicate determinations; error bars show the SEM. *No colony formation.

fore, the direct effects of TNF- $\alpha(20 \mathrm{ng} / \mathrm{ml})$ on SCF-stimulated proliferation of individually plated $\mathrm{CD} 34^{+}$progenitor cells were examined. In agreement with the colony assays, TNF- $\alpha$ inhibited SCF-induced cluster formation of single CD34 ${ }^{+}$cells by $80 \%(P=0.01$; Fig. $3 A$ ). Furthermore, TNF- $\alpha$ almost completely blocked colony formation in response to G-CSF plus SCF (Fig. 3 B). While SCF directly enhanced GM-CSF- and IL-3-induced colony formation by 152 and $185 \%$, respectively, TNF- $\alpha$ reduced the number of proliferative clones similar to what was observed in response to GM-CSF or IL-3 combined with TNF- $\alpha$ (Fig. $3 B$ ). Taken together, these data suggest that
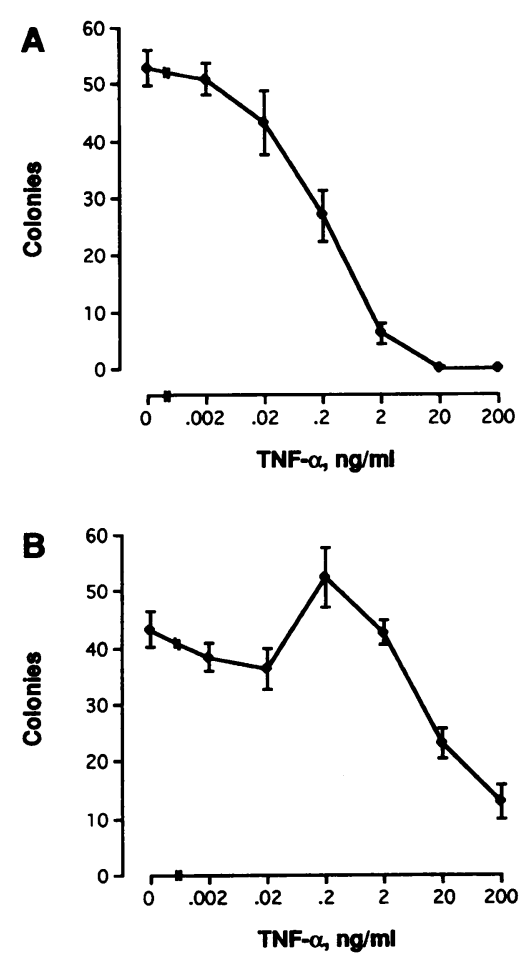

Figure 2. Concentration response of TNF- $\alpha$-induced modulation of GCSF plus SCF and GMCSF plus SCF-stimulated colony formation ( $A$ and $B$, respectively). $\mathrm{CD} 34^{+}$human bone marrow cells were separated as described in Methods and cultured in agarose at $10^{3}$ cells per dish in the presence of predetermined optimal concentrations of SCF $(50 \mathrm{ng} / \mathrm{ml})$ plus $(A) \mathrm{G}-$ CSF $(20 \mathrm{ng} / \mathrm{ml})$ or $(B)$ GM-CSF ( $50 \mathrm{ng} / \mathrm{ml}$ ) and increasing concentrations of TNF- $\alpha$. Cultures were scored for colony growth ( $>40$ cells) after $14 \mathrm{~d}$ of incubation at $37^{\circ} \mathrm{C}$ and $5 \% \mathrm{CO}_{2}$ in air. Results are presented as the mean number of colonies per $10^{3}$ cells of four experiments with duplicate determinations; error bars show the SEM.

TNF- $\alpha$ directly inhibits SCF-induced proliferation of CD34 ${ }^{+}$ progenitor cells.

Relative role of $p 55$ and p75 TNF receptors in $T N F-\alpha-$ induced inhibition of SCF-stimulated progenitor cell growth. While both TNFR-p55 and TNFR-p75 can signal TNF- $\alpha$-mediated inhibition of primitive progenitor cells such as HPP-CFC, TNFR-p55 has been shown exclusively to mediate the effects (stimulatory or inhibitory) of TNF- $\alpha$ on more mature single factor-responsive progenitor cells (28). In the present study, TNF- $\alpha$ inhibited SCF-induced cluster formation (4-40 cells) by $75 \%$. An agonistic antibody to the p55 TNF receptor (htr9) was as potent as TNF- $\alpha$ in mediating this inhibition, while an agonistic antibody to the p75 TNF receptor (paTNFR-p75) had only marginal inhibitory effect (Fig. $4 A$ ), suggesting that TNFR-p55 mainly mediates the inhibitory effects of TNF- $\alpha$ on SCF-responsive CD34 ${ }^{+}$progenitor cells.

The potent synergistic effect of SCF observed in combination with GM-CSF was inhibited by TNF- $\alpha(200 \mathrm{ng} / \mathrm{ml})$, resulting in colony numbers similar to those obtained in absence of SCF (Fig. $4 B$ ). Furthermore, a mutant TNF- $\alpha$ protein with selective activity on TNFR-p55 inhibited GM-CSF plus SCFinduced colony formation almost to the same extent as TNF- $\alpha$ itself ( 56 vs $65 \%$ ), while a TNF- $\alpha$ mutant with selective activity on TNFR-p75 had a marginal inhibitory effect of $10 \%(P$ $=0.1$ ). No additive inhibitory effects on GM-CSF plus SCFstimulated colony formation were observed when combining the two TNF- $\alpha$ mutant proteins (not shown). These results suggest that mainly TNFR-p55 mediates the inhibitory effects of TNF- $\alpha$ on GM-CSF plus SCF-responsive CD $34^{+}$progenitor cells.

Effects of TNF- $\alpha$ on GM-CSF plus SCF and IL-3 plus SCFinduced differentiation of $\mathrm{CD}_{34}{ }^{+}$cells: role of p55 and p75 

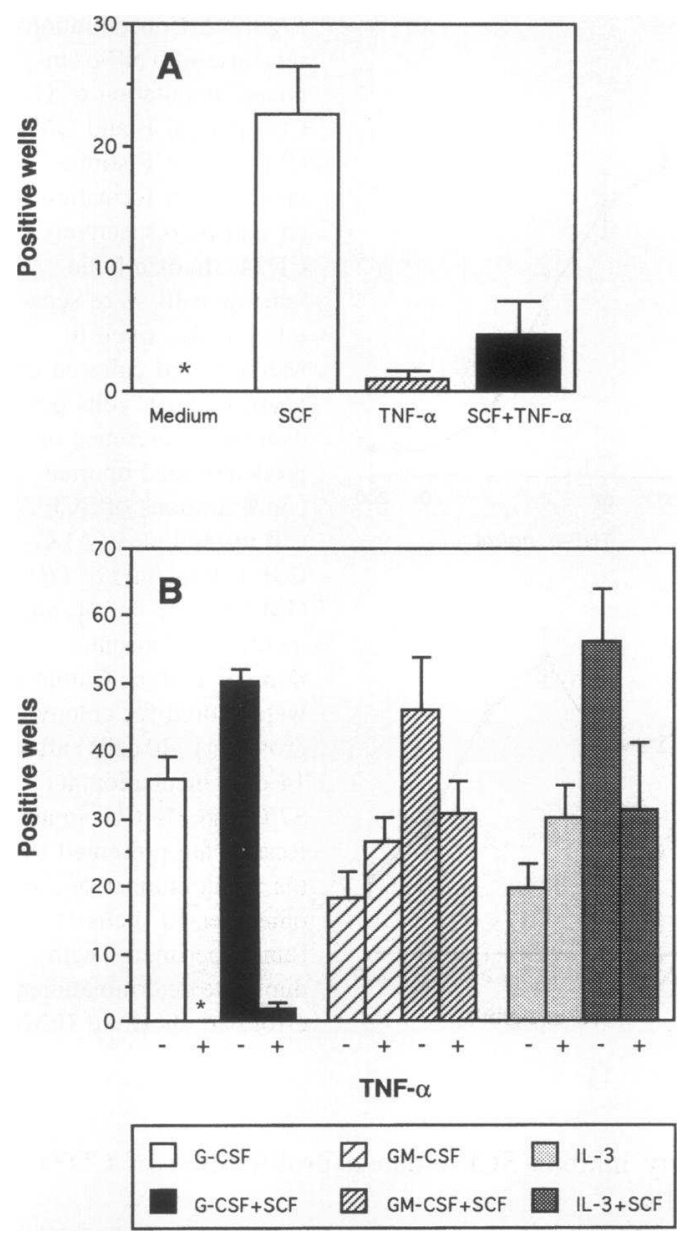

Figure 3. Direct effects of TNF- $\alpha$ on SCF-stimulated proliferation of $\mathrm{CD} 34^{+}$bone marrow progenitor cells. $\mathrm{CD} 34^{+}$cells were isolated and plated at a density of one cell per well (see Methods) in the presence or absence of TNF- $\alpha(20 \mathrm{ng} / \mathrm{ml})$. Predetermined optimal concentrations of growth factors were added as indicated, and cultures were scored for proliferation ( $>4$ cells, $A$; or $>10$ cells, $B$ ) after $14 \mathrm{~d}$ at $37^{\circ} \mathrm{C}$ and $5 \% \mathrm{CO}_{2}$ in air. Each group consisted of 300 wells, and results are presented as the mean number of positive wells per group; error bars show the SEM. $A$ represents data obtained from five independent experiments, including two experiments using a cell sorter equipped with a single-cell depositor (see Methods). $B$ includes results of four independent experiments. ${ }^{*}$ No proliferation.

TNF receptors. TNF- $\alpha$ has previously been reported to switch IL-3-induced differentiation from granulocytes to macrophages (8). In contrast, we demonstrate here that TNF- $\alpha$ in combination with IL-3 plus SCF promoted the development of $52 \pm 8 \%$ granulocytes (including metamyelocytes, bands, and polymorphonuclear neutrophils ), whereas only $13 \pm 4 \%$ granulocytes developed in TNF- $\alpha$-untreated cultures $(P<0.05$; Table I). A concomitant reduction in macrophages from $55 \pm 4$ to $36 \pm 6 \%$ and in myeloblasts from $23 \pm 4$ to $4 \pm 2 \%$ was observed. Similar results were obtained combining TNF- $\alpha$ and GM-CSF plus SCF (Table I). Although total cell proliferation was inhibited, TNF$\alpha$ promoted an absolute increase in the number of granulocytes present in the cultures after 2 wk. A TNF- $\alpha$ mutant specific for TNFR-p55 promoted a similar effect on IL-3 plus SCF-induced differentiation as TNF- $\alpha$ itself, whereas a TNFR-p75-selective TNF- $\alpha$ mutant did not affect IL-3 plus SCF-induced differentia-
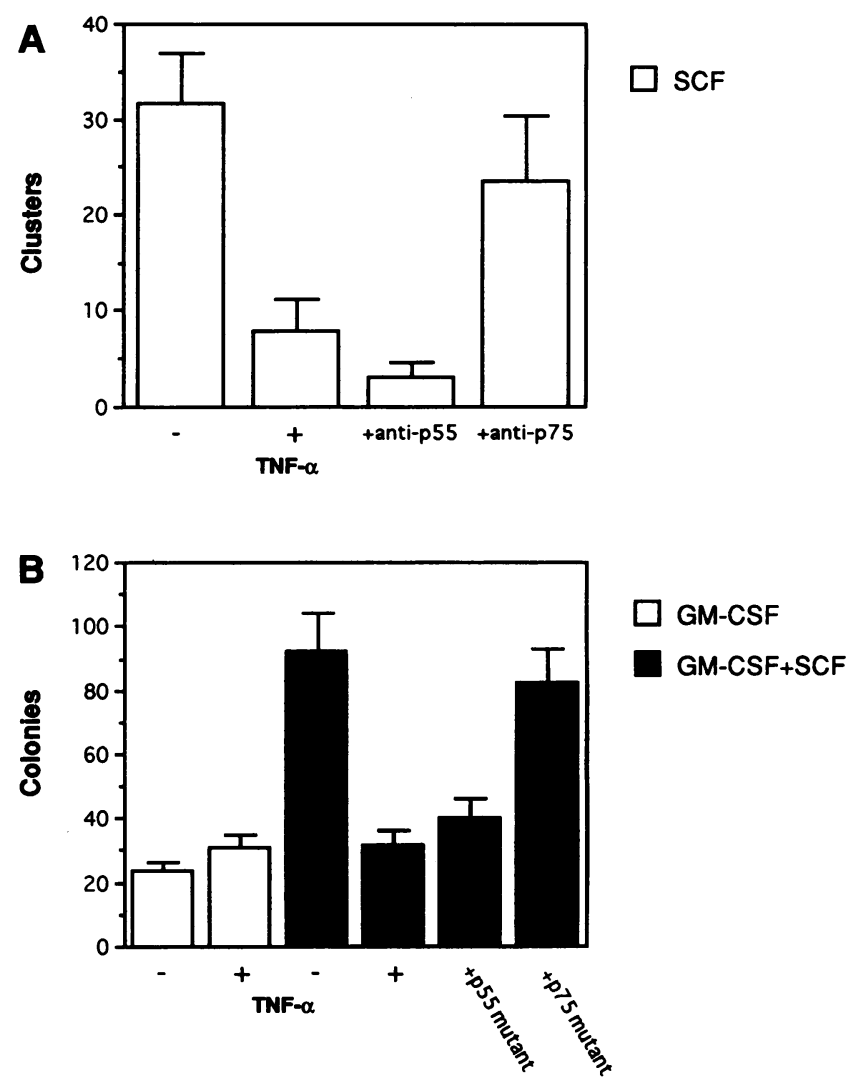

Figure 4. Relative role of $\mathrm{p} 55$ and p75 TNF receptors in TNF- $\alpha$-induced inhibition of SCF-stimulated proliferation of $\mathrm{CD} 34^{+}$progenitor cells. $\mathrm{CD} 34^{+}$cells $\left(2 \times 10^{3}\right.$ cells per dish $)$ were plated in $0.3 \%$ agarose as described in Methods. Individual cultures were supplemented as indicated with TNF- $\alpha(20 \mathrm{ng} / \mathrm{ml}, A$; or $200 \mathrm{ng} / \mathrm{ml}, B)$, htr-9 $(10 \mu \mathrm{g} / \mathrm{ml})$, paTNFR-p75 $(2 \mu \mathrm{g} / \mathrm{ml})$, p55 mutant $(200 \mathrm{ng} / \mathrm{ml})$, p75 mutant $(2 \mu \mathrm{g} /$ $\mathrm{ml}$ ), and predetermined optimal concentrations of HGFs. Clusters (4 40 cells; $A$ ) or colonies ( $>40$ cells; $B$ ) were scored after $14 \mathrm{~d}$ of incubation at $37^{\circ} \mathrm{C}$ and $5 \% \mathrm{CO}_{2}$ in air. Results are presented as the mean number of colonies per $2 \times 10^{3}$ cells of four independent experiments with duplicate determinations; error bars show the SEM.

tion (Table II). Thus, TNF- $\alpha$ through TNFR-p55 can potently enhance the differentiation of IL-3 plus SCF-stimulated CD $34^{+}$ cells into mature cells of the granulocytic lineage.

TNF- $\alpha$ downregulates c-kit cell-surface expression on $C D 34^{+}$hematopoietic progenitor cells. The ability of TNF- $\alpha$ to stimulate IL-3 and GM-CSF-induced proliferation of hematopoietic progenitor cells has been shown to correlate with its ability to upregulate GM-CSF and IL-3 receptor expression (50-52). Similarly, TNF- $\alpha$-induced inhibition of G-CSF-stimulated progenitor cell growth was correlated to G-CSF receptor downmodulation (10). It has been demonstrated previously that TGF- $\beta_{1}$ can downregulate c-kit expression on murine hematopoietic cell lines (52a). In this study, we used the SR-1 antibody to examine the ability of TNF- $\alpha$ and/or TGF- $\beta_{1}$, as well as the TNF receptor agonistic antibodies htr-9 (anti-p55) and paTNFR-p75, to modulate c-kit expression on $\mathrm{CD} 34^{+}$bone marrow cells. Of untreated $\mathrm{CD}_{3}{ }^{+}$cells, $39 \pm 3 \%$ were c-kit positive (Fig. 5). After 1, 6, and $24 \mathrm{~h}$ of treatment with TNF$\alpha(20 \mathrm{ng} / \mathrm{ml})$, the fraction of c-kit-positive cells was reduced to $36 \pm 2$ (NS), $28 \pm 4(P<0.05)$, and $26 \pm 2 \%(P<0.05)$, respectively. Furthermore, after $24 \mathrm{~h}$ of incubation, the relative 
Table I. Effects of TNF- $\alpha$ on GM-CSF Plus SCF and IL-3 Plus SCF-induced Differentiation of CD34 ${ }^{+}$Cells

\begin{tabular}{llcrrr}
\hline \multicolumn{1}{c}{ Growth factors } & Cells/ml & Myeloblasts & Promyelocytes/myelocytes & Granulocytes & Macrophages \\
\hline IL-3 + SCF & $3.5 \times 10^{5}$ & $23 \pm 4$ & $9 \pm 1$ & $13 \pm 4$ & $55 \pm 4$ \\
IL-3 + SCF + TNF- $\alpha$ & $2.0 \times 10^{5}$ & $4 \pm 2$ & $8 \pm 2$ & $52 \pm 8$ & $36 \pm 6$ \\
GM-CSF + SCF & $8.1 \times 10^{5}$ & $21 \pm 5$ & $11 \pm 3$ & $60 \pm 3$ \\
GM-CSF + SCF + TNF- $\alpha$ & $3.5 \times 10^{5}$ & $4 \pm 2$ & $9 \pm 3$ & $47 \pm 5$ & $40 \pm 5$ \\
\end{tabular}

$\mathrm{CD}_{4} 4^{+}$cells were plated in complete IMDM at a density of $2.5 \times 10^{3}$ cells $/ \mathrm{ml}$ and incubated for $14 \mathrm{~d}$ at $37^{\circ} \mathrm{C}$ and $5 \% \mathrm{CO}_{2}$ in air in the presence or absence of TNF- $\alpha(200 \mathrm{ng} / \mathrm{ml})$ and with indicated growth factors at predetermined optimal concentrations (see Methods). Cells were counted, and cell morphology was determined after May-Grünwald Giemsa staining of cytospin preparations. The results represent mean percentages \pm SEM of four separate experiments. Freshly isolated $\mathrm{CD} 34^{+}$cells contained $>90 \%$ cells with blast cell morphology.

intensity of SR-1 staining on c-kit-positive TNF- $\alpha$-treated cells was reduced by $49 \%$ as compared with TNF- $\alpha$-untreated cells (data not shown). Similarly, after 1,6 , and $24 \mathrm{~h}$ of treatment, TGF- $\beta_{1}(20 \mathrm{ng} / \mathrm{ml})$ reduced the fraction of c-kit-positive cells to $37 \pm 2(\mathrm{NS}), 31 \pm 3(P=0.09)$, and $27 \pm 4 \%(P<0.05)$, respectively (Fig. 5). When combining TNF- $\alpha$ and TGF- $\beta_{1}$, the downregulation of c-kit expression was more pronounced than by either of the two factors alone, but in a less than additive fashion. $24 \mathrm{~h}$ of treatment of $\mathrm{CD} 34^{+}$cells with the anti-TNFRp55 and anti-TNFR-p75 antibodies reduced the number of ckit-positive cells by $39(P<0.05)$ and $22 \%(P<0.05)$, respectively, suggesting that signaling through both TNF receptors can mediate the observed downregulation of c-kit cellsurface expression.

\section{Discussion}

TNF- $\alpha$ has been demonstrated to signal both inhibition and stimulation of hematopoietic progenitor cells $(1-9,28)$. These effects are mediated directly on target cells $(7,10)$ or indirectly by stimulating accessory cells to cytokine production (11-13). Recent studies from our laboratory suggest that both TNFRp55 and TNFR-p75 can mediate TNF- $\alpha$-induced inhibition of primitive hematopoietic progenitor cells requiring multiple cytokines to proliferate. In contrast, TNFR-p55 exclusively mediates stimulatory effects on more mature GM-CSF or IL-3-responsive progenitor cells, as well as potent inhibition of GCSF-induced proliferation (28). The present study extends these findings to show that TNF- $\alpha$ directly and mainly through the p55 TNF receptor can potently inhibit SCF-induced proliferation of $\mathrm{CD} 34^{+}$bone marrow progenitor cells.
Whereas TNF- $\alpha$ synergistically enhances GM-CSF and IL3 -induced proliferation of $\mathrm{CD} 34^{+}$progenitor cells, we demonstrate here that progenitors requiring both IL-3 (or GM-CSF) and SCF for growth are potently inhibited by TNF- $\alpha$. The ability of TNF- $\alpha$ to inhibit GM-CSF plus SCF and IL-3 plus SCFstimulated proliferation could be solely because of TNF- $\alpha$ inhibiting the SCF signal and/or TNF- $\alpha$ preferentially inhibiting more primitive progenitors requiring both SCF and GM-CSF or IL-3 to proliferate.

The inhibitory effects of TNF- $\alpha$ on GM-CSF plus SCFinduced colony formation occurred at higher TNF- $\alpha$ concentrations than observed for G-CSF plus SCF-induced proliferation. This could be because of the enhancement of GM-CSF-induced colony formation observed at low TNF- $\alpha$ concentrations $(0.2-$ $2 \mathrm{ng} / \mathrm{ml}$ ). In contrast, TNF- $\alpha$ potently inhibited G-CSF-stimulated colony formation, as well as SCF-induced growth at both low and high concentrations of TNF- $\alpha$ (28).

$\mathrm{CD} 4^{+}$progenitor cell proliferation induced by SCF or SCF plus GM-CSF was potently inhibited by an anti-TNFR-p55 agonistic antibody (or a p55 mutant TNF- $\alpha$ ), whereas TNFRp75 signaled little or no inhibition. This was in contrast to TNF$\boldsymbol{\alpha}$-induced inhibition of the primitive HPP-CFC which involves TNFR-p55 as well as TNFR-p75 (28). Since few or no CD34 ${ }^{+}$ HPP-CFCs are stimulated by SCF plus GM-CSF or SCF plus IL-3 (Jacobsen, S. E. W., L. S. Rusten, and F. W. Jacobsen, unpublished observations), but rather require three to five HGFs for optimal proliferation (53-59), it is possible that the p75 TNF receptor is involved in inhibition of only the most primitive progenitors. In agreement with this, TNF- $\alpha$-induced inhibition of very primitive $\mathrm{Lin}^{-} \mathrm{Sca}-1^{+}$murine HPP-CFCs is exclusively a TNFR-p75-mediated event (28a).

Table II. Role of p55 and p75 TNF Receptors in TNF- $\alpha$-induced Modulation of IL-3 Plus SCF-stimulated Differentiation of $\mathrm{CD}_{34^{+}}$Bone Marrow Cells

\begin{tabular}{lcccc}
\hline \multicolumn{1}{c}{ Growth factors } & Myeloblasts & Promyelocytes/myelocytes & Granulocytes & Macrophages \\
\hline IL-3 + SCF & $15 \pm 3$ & $31 \pm 4$ & $26 \pm 5$ & $28 \pm 8$ \\
IL-3 + SCF + TNF- $\alpha$ & $1 \pm 0$ & $10 \pm 3$ & $66 \pm 12$ & $24 \pm 12$ \\
IL-3 + SCF + p55 mutant & $2 \pm 1$ & $9 \pm 1$ & $58 \pm 13$ & $32 \pm 14$ \\
IL-3 + SCF + p75 mutant & $13 \pm 2$ & $34 \pm 2$ & $32 \pm 4$ & $22 \pm 2$ \\
\hline
\end{tabular}

$\mathrm{CD} 34^{+}$cells were plated in complete IMDM at a density of $5.0 \times 10^{3}$ cells $/ \mathrm{ml}$ and incubated for $14 \mathrm{~d}$ at $37^{\circ} \mathrm{C}$ and $5 \% \mathrm{CO}_{2}$ in air in the presence of IL-3 plus SCF at predetermined optimal concentrations (see Methods). TNF- $\alpha$ (200 ng/ml), a TNF- $\alpha$ mutant specific for TNFR-p55 (200 ng/ $\mathrm{ml})$, or a TNF- $\alpha$ mutant specific for TNFR-p75 $(2 \mu \mathrm{g} / \mathrm{ml})$ was added as indicated. Cell morphology was determined after May-Grünwald Giemsa staining of cytospin preparations. The results represent mean percentages \pm SEM of three separate experiments. 


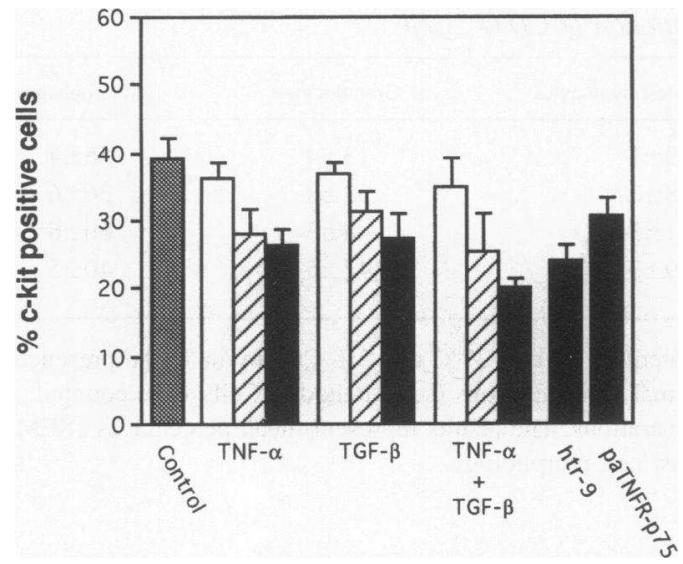

Figure 5. Role of p55 and p75 TNF receptors in TNF- $\alpha$-induced downregulation of c-kit cell-surface expression. Freshly isolated $\mathrm{CD} 34^{+}$cells were incubated in complete IMDM at $37^{\circ} \mathrm{C}$ and $5 \% \mathrm{CO}_{2}$ in air as described in Methods. TNF- $\alpha(20 \mathrm{ng} / \mathrm{ml})$, TGF- $\beta(20 \mathrm{ng} / \mathrm{ml})$, antip55 (htr-9; $10 \mu \mathrm{g} / \mathrm{ml}$ ), or anti-p75 (paTNFR-p75; $2 \mu \mathrm{g} / \mathrm{ml}$ ) was added $1(\square), 6(\square)$, or $24 \mathrm{~h}(\square)$ before harvest. Control cells were incubated for $24 \mathrm{~h}$ in complete IMDM without any supplements. The cells were washed and stained with the SR-1 antibody (see Methods) and analyzed by flow cytometry. The results are presented as the mean fraction of ckit-positive cells and represent at least four independent experiments; error bars show the SEM.

TNF- $\alpha$ has been reported to inhibit terminal granulocytic differentiation of IL-3 as well as G-CSF-dependent progenitor cells (6-8). Of interest, we demonstrate here that TNF- $\alpha$ through its p55 receptor enhances terminal granulocytic differentiation of progenitors proliferating in response to SCF in combination with IL-3 or GM-CSF, suggesting that TNF- $\alpha$ can bifunctionally affect the proliferation as well as differentiation of hematopoietic progenitors depending on the growth factor (s) it interacts with.

Modulation of cell-surface receptor expression has been proposed as a mechanism by which both stimulatory and inhibitory effects of HGFs are mediated (10, 50, 52, 60-62). In particular, TNF- $\alpha$ has been demonstrated to potently inhibit G-CSF-induced proliferation, and this correlates well with its ability to almost completely downregulate the expression of cell-surface receptors for G-CSF on normal and leukemic myeloid cells $(10,60,61)$. In contrast, TNF- $\alpha$ can upregulate cell-surface receptors for GM-CSF and IL-3 on acute myeloid leukemia blasts, as well as on normal hematopoietic progenitor cells, and this is associated with an enhancement of GM-CSF and IL3 -stimulated growth $(7,50,52)$. Of interest, a recent study demonstrated that TNF- $\alpha$ could enhance c-kit mRNA expression and upregulate c-kit cell-surface expression on acute myeloid leukemia blasts, and this was correlated with synergy between TNF- $\alpha$ and SCF (63). In the present study, TNF- $\alpha$ inhibited SCF-induced proliferation and downmodulated c-kit expression on normal $\mathrm{CD}_{3} 4^{+}$progenitor cells. Therefore, it appears that TNF- $\alpha$ can bidirectionally affect SCF-stimulated cell growth as well as c-kit expression. However, the moderate effects of TNF- $\alpha$ on c-kit expression compared with its potent inhibitory effects on SCF-stimulated proliferation implicate the involvement of other more important mechanisms. In other cell systems it has been shown that TNF- $\alpha$ can modify the level of phosphorylation of RB and p53 proteins (64).
In conclusion, TNF- $\alpha$ is a potent inhibitor of SCF, a key regulator of hematopoiesis. Whereas numerous cytokines have been demonstrated to synergistically enhance SCF-stimulated hematopoiesis $(34-43)$, this is only the second report demonstrating a cytokine capable of inhibiting the SCF response (65). Whether TGF- $\beta$ (65) and TNF- $\alpha$ are unique in their ability to antagonize the effects of SCF remains to be determined.

\section{Acknowledgments}

This work was supported by The Norwegian Cancer Society and The Norwegian Research Council.

\section{References}

1. Degliantoni, G., M. Murphy, M. Kobayashi, M. K. Francis, B. Perussia, and G. Trinchieri. 1985. Natural killer (NK) cell-derived hematopoietic colonyinhibiting activity and NK cytotoxic factor. Relationship with tumor necrosis factor and synergism with immune interferon. J. Exp. Med. 162:1512-1530.

2. Broxmeyer, H. E., D. E. Williams, L. Lu, S. Cooper, S. L. Anderson, G. S. Beyer, R. Hoffman, and B. Y. Rubin. 1986. The suppressive influences of human tumor necrosis factors on bone marrow hematopoietic progenitor cells from normal donors and patients with leukemia: synergism of tumor necrosis factor and interferon- $\gamma$. J. Immunol. 136:4487-4495.

3. Cuturi, M. C., M. Murphy, M. P. Costa-Giomi, R. Weinmann, B. Perussia, and G. Trinchieri. 1987. Independent regulation of tumor necrosis factor and lymphotoxin production by human peripheral blood lymphocytes. J. Exp. Med. 165:1581-1594.

4. Murase, T., T. Hotta, H. Saito, and R. Ohno. 1987. Effect of recombinant human tumor necrosis factor on the colony growth of human leukemia progenitor cells and normal hematopoietic progenitor cells. Blood. 69:467-472.

5. Murphy, M., B. Perussia, and G. Trinchieri. 1988. Effects of recombinant tumor necrosis factor, lymphotoxin, and immune interferon on proliferation and differentiation of enriched hematopoietic precursor cells. Exp. Hematol. (NY). $16: 131-138$.

6. Backx, B., L. Broeders, F. J. Bot, and B. Lowenberg. 1991. Positive and negative effects of tumor necrosis factor on colony growth from highly purified normal marrow progenitors. Leukemia (Baltimore). 5:66-70.

7. Caux, C., S. Saeland, C. Favre, V. Duvert, P. Mannoni, and J. Banchereau. 1990. Tumor necrosis factor-alpha strongly potentiates interleukin-3 and granulocyte-macrophage colony-stimulating factor-induced proliferation of human

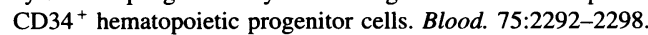

8. Caux, C., C. Favre, S. Saeland, V. Duvert, I. Durand, P. Mannoni, and J. Banchereau. 1991. Potentiation of early hematopoiesis by tumor necrosis factor$\alpha$ is followed by inhibition of granulopoietic differentiation and proliferation. Blood. 78:635-644.

9. Caux, C., I. Durand, I. Moreau, V. Duvert, S. Saeland, and J. Banchereau. 1993. Tumor necrosis factor $\alpha$ cooperates with interleukin 3 in the recruitment of a primitive subset of human CD34 ${ }^{+}$progenitors. J. Exp. Med. 177:1815-1820.

10. Jacobsen, S. E. W., F. W. Ruscetti, C. M. Dubois, and J. R. Keller. 1992. Tumor necrosis factor $\alpha$ directly and indirectly regulates hematopoietic progenitor cell proliferation: Role of colony-stimulating factor receptor modulation. J. Exp. Med. 175:1759-1772.

11. Munker, R., J. Gasson, M. Ogawa, and H. P. Koeffler. 1986. Recombinant human TNF induces production of granulocyte-monocyte colony-stimulating factor. Nature (Lond.). 323:79-82.

12. Oster, W., A. Lindemann, S. Horn, R. Mertelsmann, and F. Herrmann. 1987. Tumor necrosis factor (TNF)-alpha but not TNF-beta induces secretion of colony stimulating factor for macrophages (CSF-1) by human monocytes. Blood. 70:1700-1703.

13. Koeffler, H. P., J. Gasson, J. Ranyard, L. Souza, M. Shepard, and R. Munker. 1987. Recombinant human TNF- $\alpha$ stimulates production of granulocyte colony-stimulating factor. Blood. 70:55-59.

14. Schall, T. J., M. Lewis, K. J. Koller, A. Lee, G. C. Rice, G. H. W. Wong, T. Gatanaga, G. A. Granger, R. Lentz, H. Raab, et al. 1990. Molecular cloning and expression of a receptor for human tumor necrosis factor. Cell. 61:361-370.

15. Loetscher, H., Y. C. E. Pan, H. W. Lahm, R. Gentz, M. Brockhaus, H. Tabuchi, and W. Lesslauer. 1990. Molecular cloning and expression of the human $55 \mathrm{kd}$ tumor necrosis factor receptor. Cell. 61:351-359.

16. Heller, R. A., K. Song, M. A. Onasch, W. H. Fischer, D. Chang, and G. M. Ringold. 1990. Complementary DNA cloning of a receptor for tumor necrosis factor and demonstration of a shed form of the receptor. Proc. Natl. Acad. Sci. USA. 87:6151-6155.

17. Dembic, Z., H. Loetscher, U. Gubler, Y. C. Pan, H. W. Lahm, R. Gentz, 
M. Brockhaus, and W. Lesslauer. 1990. Two human TNF receptors have similar extracellular, but distinct intracellular, domain sequences. Cytokine. 2:231-237.

18. Smith, C. A., T. Davis, D. Anderson, L. Solam, M. P. Beckmann, R. Jerzy, S. K. Dower, D. Cosman, and R. G. Goodwin. 1990. A receptor for tumor necrosis factor defines an unusual family of cellular and viral proteins. Science (Wash. DC). 248:1019-1023.

19. Sugarman, B. J., B. B. Aggarwal, P. E. Hass, I. S. Figari, M. A. Palladino, and H. M. Shepard. 1985. Recombinant human tumor necrosis factor- $\alpha$ : effects on proliferation of normal and transformed cells in vitro. Science (Wash. DC). 230:943-945.

20. Tracey, K. J., B. Beutler, S. F. Lowry, J. Merryweather, S. Wolpe, I. W. Milsark, R. J. Hariri, T. J. Fahey III, A. Zentella, J. D. Albert, et al. 1986. Shock and tissue injury induced by recombinant human cachectin. Science (Wash. DC). 234:470-474.

21. Retsas, S., M. Leslie, and D. Bottomley. 1989. Intralesional tumor necrosis factor combined with interferon gamma in metastatic melanoma. $\mathrm{Br}$. Med. J. 298:1290-1291.

22. Lienard, D., P. Ewalenko, J. J. Delmotte, N. Renard, and F. J. Lejeune. 1992. High-dose recombinant tumor necrosis factor alpha in combination with interferon gamma and melphalan in isolation perfusion of the limbs for melanoma and sarcoma. J. Clin. Oncol. 10:52-60.

23. Fransen, L., M. R. Ruysschaert, J. Van der Heyden, and W. Fiers. 1986. Recombinant tumor necrosis factor: species specificity for a variety of human and murine transformed cell lines. Cell. Immunol. 100:260-267.

24. Everaerdt, B., P. Brouckaert, A. Shaw, and W. Fiers. 1989. Four different interleukin-1 species sensitize to the lethal action of tumor necrosis factor. Biochem. Biophys. Res. Commun. 163:378-385.

25. Lewis, M., L. A. Tartaglia, A. Lee, G. L. Bennett, G. C. Rice, G. H. W Wong, E. Y. Chen, and D. V. Goeddel. 1991. Cloning and expression of cDNAs for two distinct murine tumor necrosis factor receptors demonstrate one receptor is species specific. Proc. Natl. Acad. Sci. USA. 88:2830-2834.

26. Van Ostade, X., P. Vandenabeele, B. Everaerdt, H. Loetscher, R. Gentz, M. Brockhaus, W. Lesslauer, J. Tavernier, P. Brouckaert, and W. Fiers. 1993. Human TNF mutants with selective activity on the p55 receptor. Nature (Lond.). 361:266-269.

27. Balkwill, F. 1993. Improving the formula. Nature (Lond.). 361:206-207.

28. Rusten, L. S., F. W. Jacobsen, W. Lesslauer, H. Loetscher, E. B. Smeland, and S. E. W. Jacobsen. 1994. Bifunctional effects of TNF- $\alpha$ on the growth of mature and primitive human hematopoietic progenitor cells: involvement of p55 and p75 TNF receptors. Blood. In press.

28a. Jacobsen, F. W., M. Rothe, L. S. Rusten, D. V. Goeddel, E. B. Smeland, L. Slørdal, and S. E. W. Jacobsen. 1994. Novel role of the 75-kDa tumor necrosis factor (TNF) receptor: inhibition of early hematopoiesis. Proc. Natl. Acad. Sci. USA. In press.

29. Geissler, E. N., M. A. Ryan, and D. E. Housman. 1988. The dominantwhite spotting (W) locus of the mouse encodes the c-kit proto-oncogene. Cell. 55:185-192.

30. Zsebo, K. M., D. A. Williams, E. N. Geissler, V. C. Broudy, F. H. Martin, H. L. Atkins, R. Y. Hsu, N. C. Birkett, K. H. Okino, D. C. Murdock, et al. 1990. Stem cell factor is encoded at the S1 locus of the mouse and is the ligand for the c-kit tyrosine kinase receptor. Cell. 63:213-224.

31. Zsebo, K. M., J. Wypych, I. K. McNiece, H. S. Lu, K. A. Smith, S. B. Karkare, R. K. Sachdev, V. N. Yuschenkoff, N. C. Birkett, L. R. Williams, et al. 1990. Identification, purification, and biological characterization of hematopoietic stem cell factor from buffalo rat liver-conditioned medium. Cell. 63:195-201.

32. Williams, D. E., J. Eisenman, A. Baird, C. Rauch, K. Van Ness, C. J. March, L. S. Park, U. Martin, D. Y. Mochizuki, H. S. Boswell, et al. 1990. Identification of a ligand for the c-kit proto-oncogene. Cell. 63:167-174.

33. Martin, F. H., S. V. Suggs, K. E. Langley, H. S. Lu, J. Ting, K. H. Okino, C. F. Morris, I. K. McNiece, F. W. Jacobsen, E. A. Mendiaz, et al. 1990. Primary structure and functional expression of rat and human stem cell factor DNAs. Cell. 63:203-211.

34. Broxmeyer, H. E., S. Cooper, L. Lu, G. Hangoc, D. Anderson, D. Cosman, S. D. Lyman, and D. E. Williams. 1991. Effect of murine mast cell growth factor (c-kit proto-oncogene ligand) on colony formation by human marrow hematopoietic progenitor cells. Blood. 77:2142-2149.

35. McNiece, I. K., K. E. Langley, and K. E. Zsebo. 1991. Recombinant human stem cell factor synergises with GM-CSF, G-CSF, IL-3 and Epo to stimulate human progenitor cells of the myeloid and erythroid lineages. Exp. Hematol. (NY). 19:226-231.

36. Bernstein, I. D., R. G. Andrews, and K. M. Zsebo. 1991. Recombinant human stem cell factor enhances the formation of colonies by $\mathrm{CD} 34^{+}$and $\mathrm{CD} 34^{+} \mathrm{lin}^{-}$cells, and the generation of colony-forming cell progeny from $\mathrm{CD} 4^{+}{ }^{-}$in $^{-}$cells cultured with interleukin-3, granulocyte colony-stimulating factor, or granulocyte-macrophage colony-stimulating factor. Blood. 77:2316-2321.

37. Heyworth, C. M., A. D. Whetton, S. Nicholls, K. Zsebo, and T. M. Dexter. 1992. Stem cell factor directly stimulates the development of enriched granulocyte-macrophage colony-forming cells and promotes the effects of other colony-stimulating factors. Blood. 80:2230-2236.

38. Haylock, D. N., L. B. To, T. L. Dowse, C. A. Juttner, and P. J. Simmons.
1992. Ex vivo expansion and maturation of peripheral blood $\mathrm{CD}_{3} 4^{+}$cells into the myeloid lineage. Blood. 80:1405-1412.

39. Muench, M. O., M. T. Firpo, and M. A. S. Moore. 1993. Bone marrow transplantation with interleukin-1 plus kit-ligand ex vivo expanded bone marrow accelerates hematopoietic reconstitution in mice without the loss of stem cell lineage and proliferative potential. Blood. 81:3463-3473.

40. Briddell, R. A., E. Bruno, R. J. Cooper, J. E. Brandt, and R. Hoffman. 1991. Effect of c-kit ligand on in vitro human megakaryocytopoiesis. Blood. 78:2854-2859.

41. Avraham, H., E. Vannier, S. Cowley, S. Jiang, S. Chi, C. A. Dinarello, K. M. Zsebo, and J. E. Groopman. 1992. Effects of the stem cell factor, c-kit ligand, on human megakaryocytic cells. Blood. 79:365-371.

42. Tsuji, K., S. D. Lyman, T. Sudo, S. C. Clark, and M. Ogawa. 1992. Enhancement of murine hematopoiesis by synergistic interactions between stee factor (ligand for c-kit), interleukin-11, and other early acting factors in culture. Blood. 79:2855-2860.

43. Jacobsen, S. E. W., O. P. Veiby, and E. B. Smeland. 1993. Cytotoxic lymphocyte maturation factor (interleukin 12) is a synergistic growth factor for hematopoietic stem cells. J. Exp. Med. 178:413-418.

44. Loetscher, H., D. Stueber, D. Banner, F. Mackay, and W. Lesslauer. 1993 Human tumor necrosis factor $\alpha$ (TNF $\alpha$ ) mutants with exclusive specificity for the 55-kDa or 75-kDa TNF receptors. J. Biol. Chem. 268:26350-26357.

45. Gehr, G., R. Gentz, M. Brockhaus, H. Loetscher, and W. Lesslauer. 1992. Both tumor necrosis factor receptor types mediate proliferative signals in human mononuclear cell activation. J. Immunol. 149:911-917.

46. Brockhaus, M., H. J. Schoenfeld, E. J. Schlaeger, W. Hunziker, W. Lesslauer, and H. Loetscher. 1990. Identification of two types of tumor necrosis factor receptors on human cell lines by monoclonal antibodies. Proc. Natl. Acad. Sci. USA. 87:3127-3131.

47. Smeland, E. B., S. Funderud, G. Kvalheim, G. Gaudernack, A.-M. Rasmussen, L. Rusten, M. Y. Wang, R. W. Tindle, H. K. Blomhoff, and T. Egeland. 1992. Isolation and characterization of human hematopoietic progenitor cells: an effective method for positive selection of $\mathrm{CD} 34^{+}$cells. Leukemia (Baltimore). 6:845-852.

48. Metcalf, D. 1970. Studies on colony formation in vitro by mouse bone marrow cells. Action of colony stimulating factor. J. Cell. Physiol. 76:89-100.

49. Broudy, V. C., N. Lin, K. M. Zsebo, N. C. Birkett, K. A. Smith, I. D. Bernstein, and T. Papayannopoulou. 1992. Isolation and characterization of a monoclonal antibody that recognizes the human c-kit receptor. Blood. 79:338 346.

50. Elbaz, O., L. M. Budel, H. Hoogerbrugge, I. P. Touw, R. Delwel, L. A Mahmoud, and B. Løwenberg. 1991. Tumor necrosis factor regulates the expression of granulocyte-macrophage colony-stimulating factor and interleukin-3 receptors on human acute myeloid leukemia cells. Blood. 77:989-995.

51. Watanabe, Y., T. Kitamura, K. Hayashida, and A. Miyajima. 1992. Monoclonal antibody against the common $\beta$ subunit $(\beta c)$ of the human interleukin-3 (IL-3), IL-5, and granulocyte-macrophage colony-stimulating factor receptors shows upregulation of $\beta c$ by IL-1 and tumor necrosis factor- $\alpha$. Blood. 80:22152220 .

52. Sato, N., C. Caux, T. Kitamura, Y. Watanabe, K. Arai, J. Banchereau, and A. Miyajima. 1993. Expression and factor-dependent modulation of the interleukin-3 receptor subunits on human hematopoietic cells. Blood. 82:752-761.

52a. Dubois, C. M., M. Ortiz, F. W. Ruscetti, J. Stankova, and J. R. Keller. 1994. Transforming growth factor beta regulates c-kit message stability and cellsurface protein expression in hematopoietic progenitors. Blood. In press.

53. Bradley, T. R., and G. S. Hodgson. 1979. Detection of primitive macrophage progenitor cells in mouse bone marrow. Blood. 54:1446-1450.

54. Heimfeld, S., S. Hudak, I. Weissman, and D. Rennick. 1991. The in vitro response of phenotypically defined mouse stem cells and myeloerythroid progenitors to single or multiple growth factors. Proc. Natl. Acad. Sci. USA. 88:9902-9906.

55. Ikebuchi, K., G. G. Wong, S. C. Clark, J. N. Ihle, Y. Hirai, and M. Ogawa 1987. Interleukin 6 enhancement of interleukin 3-dependent proliferation of multipotential hematopoietic progenitors. Proc. Natl. Acad. Sci. USA. 84:9035-9039.

56. Ikebuchi, K., S. C. Clark, J. N. Ihle, L. M. Souza, and M. Ogawa. 1988. Granulocyte colony-stimulating factor enhances interleukin 3-dependent proliferation of multipotential hematopoietic progenitors. Proc. Natl. Acad. Sci. USA. 85:3445-3449.

57. Iscove, N. N., A. R. Shaw, and G. Keller. 1989. Net increase of pluripotential hematopoietic precursors in suspension culture in response to IL-1 and IL-3. J. Immunol. 142:2332-2337.

58. McNiece, I. K., F. M. Stewart, D. M. Deacon, D. S. Temeles, K. M Zsebo, S. C. Clark, and P. J. Quesenberry. 1989. Detection of a human CFC with a high proliferative potential. Blood. 74:609-612.

59. Brandt, J., R. A. Briddell, E. F. Srour, T. B. Leemhuis, and R. Hoffman 1992. Role of c-kit ligand in the expansion of human hematopoietic progenitor cells. Blood. 79:634-641.

60. Elbaz, O., L. M. Budel, H. Hoogerbrugge, I. P. Touw, R. Delwel, L. A. Mahmoud, and B. Löwenberg. 1991. Tumor necrosis factor downregulates 
granulocyte-colony-stimulating factor receptor expression on human acute myeloid leukemia cells and granulocytes. J. Clin. Invest. 87:838-841.

61. Shieh, J. H., R. H. F. Peterson, and M. A. S. Moore. 1991. Modulation of granulocyte colony-stimulating factor receptors on murine peritoneal exudate macrophages by tumor necrosis factor- $\alpha$. J. Immunol. 146:2648-2653.

62. Jacobsen, S. E. W., F. W. Ruscetti, C. M. Dubois, J. Wine, and J. R. Keller. 1992. Induction of colony-stimulating factor receptor expression on hematopoietic progenitor cells: proposed mechanism for growth factor synergism. Blood. 80:678-687.

63. Brach, M. A., H. J. Bühring, H. J. Gruss, L. K. Ashman, W. D. Ludwig, R. H. Mertelsmann, and F. Herrmann. 1992. Functional expression of c-kit by acute myelogenous leukemia blasts is enhanced by tumor necrosis factor- $\alpha$ through posttranscriptional mRNA stabilization by a labile protein. Blood. $80: 1224-1230$.

64. Guy, G. R., X. Cao, S. P. Chua, and Y. H. Tan. 1992. Okadaic acid mimics multiple changes in early protein phosphorylation and gene expression induced by tumor necrosis factor or interleukin-1. J. Biol. Chem. 267: 1846-1852.

65. McNiece, I. K., I. Bertoncello, J. R. Keller, F. W. Ruscetti, C. A. Hartley, and K. M. Zsebo. 1992. Transforming growth factor $\beta$ inhibits the action of stem cell factor on mouse and human hematopoietic progenitors. Int. J. Cell Cloning. 10:80-86. 